\title{
Integrated Pest Management for Acacia: Prospects and Challenges
}

Jyoti Chauhan ${ }^{1}$, Ishan Saini ${ }^{1}$, Tarun Kumar $^{2}$ and Prashant Kaushik ${ }^{3,4^{*}}$

${ }^{1}$ Department of Botany, Kurukshetra University Kurukshetra, 136119 Kurukshetra, India

${ }^{2}$ Department of Forestry, Chaudhary Charan Singh Haryana Agricultural University, 125004 Hisar, India

${ }^{3}$ Instituto de Conservación y Mejora de la Agrodiversidad Valenciana, UniversitatPolitécnicade Valencia, 46022 Valencia, Spain

${ }^{4}$ Nagano University, 1088 Komaki, Ueda, 386-0031 Nagano, Japan

Correspondance: prakau@doctor.upv.es

\begin{abstract}
Species of Acacia have been extensively entrenched in the tropical, and semi-arid regions. Acacia species have been bounteous faces the pest and pathogenic pressure. Integrated Pest Management (IPM) is an immensely important aspect of producing a healthy Acacia plantation without harmful impacts on the environment. Here an attempt was made to determine the possibilities of integrated pest management for Acacia. Overall, this information will be helpful to increase awareness about the integrated pest management of the members of the genus Acacia.
\end{abstract}

Keywords: Acacia, insects, pests, management

\section{Introduction}

Forests are considered as one of the most delicate ecosystems on earth because forests are 
threatened by the non-native pests and pathogens (Wingfield et al., 2010). Trees and forests like a number of other crops are afflicted by an attack by insect pests plus diseases that result in lousy tree growth, bad timber quality, and in several instances, destruction and minimization of forest cover. With the ever-increasing human and livestock population, the amount of forest per capita is declining, particularly in the less industrialized or developing areas of the world (Wardle et al. 2004). It is estimated that the land under forest in developing countries is more than half of the forested land on earth. Considerable work is thus required in order to boost the output of the existing forests and also to afforest ideal areas. Moreover, we cannot ignore when it comes to the threats caused by forest pathogens and pests, which got amplified further by climate changes and global trade (Vitousek et al. 1989).

In this direction, a massive loss of forests, particularly by insects and invasive pests has become severe in recent years, worldwide (MacLeod et al., 2010). Under the particular circumstance, invasive pests and pathogens might be transferred to species that are native to vector. Then invasive pests can become vectors for indigenous or perhaps previously developed invasive pathogens (Wingfield et al., 2016). Several species of Acacia (particularly A. nilotica and A. catechu) are served as valuable trees of agroforestry system in India particularly the semi-arid zone of the country, because of their multipurpose uses as the critical source of timber or woody products and also of their potent therapeutic values (Chauhan et al., 2020). Sustained forestry generation of forest materials in arid and semi-arid aspects of India is of essential importance for the life support devices of the nation (Muzika RM 2017).

However, Acacias are symbiotically associated with various symbionts like ants, microbes, 
especially Arbuscular Mycorrhizal Fungi (AMF) that allow Acacias to generate a barrier against plant pathogens and pests even though some microbial strains are capable of spearing pathogenicity, either from other infected plants growing in the vicinity or due to human activities (Saini et al., 2019a; Saini et al., 2019b). Insect pests and diseases comprise the main biological determinants of forest efficiency, thus offsetting the attempt in improving wood output. In the forests as well as woody ecosystem the standard emergence, as well as the occurrence of the nonnative species of insects and pathogens, start to be highly deplorable (Paine et al., 2011; Wardle et al., 2017). This newly appeared association of pests and pathogens pressurize and threaten the same trees that exist in their precisely the same indigenous environment (Mattson et al.,2007; Wingfield et al., 2010; Dudley et al., 2012).

In the past few years, the Acacia species(mainly A. catechu and A. nilotica) are planted on a large scale especially in the tropical and semi-arid environment due to their rapid growth in this environment. Now, these species become the critical components of the forestry or agroforestry industry in this environment (Chauhan et al., 2020). The forest sector related with the plantation of Acacia species severely affected due to severe impact of pests and it drastically reduced the growth and development of Acacia species and strenuously jeopardise the future of plantation forestry in the entire world. The emergence of pest and pathogens on the plantation of invasive alien species of Acacia exactly followed the similar patterns as that of invasive species of Eucalyptus (Goodland and Healey, 1996; Wylie and Speight, 2012).

The native insects and pathogens chiefly that showed wide range towards their host are the responsible agents for creating the various type of pathogenic diseases and insect pests (Trang et 
al., 2018). In South Africa, Phytophthora sp. found as a responsible agent for the root disease of A. mearnsii, and wattle bagworm (insect) was found to be the causal agent for the defoliation of the A.mearnsii (Van der Putten WH,2007; Kirsten et al., 2003). In South-east Asia, the native Ganoderma, Helopeltis sp. (insect) and larvae of Lepidopteran insect (Plusia sp.) are proved as the causal organism of root rot disease, shoot disease, and defoliation of A. crassicarpa and A. mangium respectively. Different species of Acacia are found to be sensitive and primarily damaged or destroyed by various groups of insect pests (such as Coleoptera, Lepidoptera, Hemiptera and Orthoptera) (Tsopelas et al., 2003).

Integrated Pest Management (IPM) works by managing the ecosystem. It mainly focuses on longterm prevention of pests or their damage by managing the ecosystem through proper strategy. Integrated pest management (IPM) strategy and tool: IPM includes the development and use of chemical, natural, biological and biotech products for pest control (Zettler et al., 1990). Complete information about pest living help to stop unwanted damage of insects species since, in several instances, a particular number of pests could be accepted (Koshiya et al., 2003). Growing plant life, which is tailored for their growing conditions, growing them in the correct spot, giving suitable interest to the water of theirs and also food requirements as the plant needs (Zettler et al., 1990). In this review article, an attempt was made to determine the possibilities of integrated pest management for Acacia.

\section{Management approaches}

Silvicultural interventions which lead to wounds should, therefore, be stayed away from during times of higher pest actions (Hayslett et al. 2008; Heath et al. 2009b). In exotic southeast Asia, 
nitidulid and ambrosia beetles are contained in Acacia plantations and also considered essential vectors of $C$. manginecans, although their activity hasn't been administered (Tarigan et al. 2011; Brawner et al. 2015). There is an expectation that insect activity will occur year-round (Wolda 1988) though. Because of the dynamics of parasitism and plant investment in anti-herbivore defences, populations may be higher during the dry than wet season (Dyer et al. 2012). Wound dressings provide a physical barrier to Ceratocystis infection as well as inhibiting fungal growth (Harrington 2008), and low toxicity treatments have been developed. Most direct and conventional methods of control are the use of fungicides, insecticides and pesticides. The Acacia seeds after their treatment are sowing in the nursery beds. Seeds are sown either by dibbling method or by broadcast sowing method. However, out of these two methods, the dibbling method is used preferably. The seedlings of A nilotica are infrequently nurtured in the nursery beds. Generally, polythene containers are used for their growth (Ferreira et al. 2017). In each polythene bag or container, at least two or three adequately treated seeds (about $1.5 \mathrm{~cm}$ deep) are sown during February-March before their transplantation into the field. Polythene Bags or containers have the soil mixture in which soil and compost are present in the ratio of $2: 1$. In vitro tissue should be derived from healthy plants, raised in closed facilities and grown on sterilized media (Ribeiro et al. 1988).

\section{Physical methods}

Removal of pest from the particular desired place through physical means. For example, by using barriers, traps and thorough vacuuming. The boiling water as well as acid remedies, however, most likely perform like a partial sterilization therapy for microorganisms or maybe microfauna borne 
superficially on the seed coat. The acid pretreatment is acute, having been employed effectively with A. mangium, but isn't suited to other species. An IPM boll weevil capture in the industry (Kim et al., 2001). Seeds are cleaned of all extraneous material and then sealed in laminated plastic bags containing carbon dioxide for two weeks, before entering the storage areas. The seed also treated with methyl bromide to avoid any type of contaminant (Dudley et al.,2012). As noted above, the hot water and acid scarification methods of breaking dormancy are extra insurance against insect pest infestation. However, these measures may not be completely effective where insect larvae are sequestered within substantial seeds treatment. For the storage of seeds basket or tins and gunny bags can be used (Zettler et al., 1990).

The cold and dry places with proper circulation of air must be selected for seed storage. For long term duration, the essential requirement is that the seeds should be wholly air-dried and should be kept in airtight containers. The seed coat of Acacia seeds is tough and impermeable. So the pretreatment becomes an essential requirement to accelerate the germination (Wardle et al. 2004). For this purpose, pods of Acacia species are used for the animal feed. Out of these four treatments, the hot water treatment of Acacia seeds proved as protected, instantaneous and efficient method and hence recommended for seed treatment. Trichilogaster sp. and the larvae form galls within the flower buds (and occasionally in vegetative tissue) of Acacia species resulting in reduced seed production, reduced biomass and in some cases tree mortality. Some species develop entirely in vegetative tissue of the host Acacia (Koul, 2002).

\section{Biological methods}


Biocontrol is an environmentally friendly approach and effective method of reducing or mitigating the pests and their damaging effects by the application of characteristics of the innate antagonist. Biological control is a technology by which pests such as mites, insects, weeds and diseases causal agents are efficiently destroyed with the help of microbial activities. In practice, there are few examples of successful biological control in forest trees (Wingfield et al.2008; Garnas et al. 2016). Bacteria that live internally in plant tissue without causing any negative impact on their host are recognized as endophytic bacteria (Schulz and Gray 2013). Some have mutualistic associations with the host plants of theirs as well as an ability to live as facultative or obligate endophytes at various phases in their life cycle (Hardoim et al. 2008). The vast majority of the investigation into endophytic bacteria has been with horticultural and crops (Palumbo and Kobayashi 2000). Nonetheless, many species of endophytic bacteria have been isolated from woody species (Palumbo and Kobayashi 2000; Hinton and Bacon 2006; Izumi 2011). The more abundant biomass dynamics of trees likely offer a steady habitat for a diverse assortment of endophytes (Izumi 2011) and also increase the chance that they might perform a role as BCAs against vascular diseases like Ceratocystis (Thomma and Yadeta 2013).

Bacterial endophytes suppress plant diseases through the production of enzymes, antifungal and antibacterial compounds (allelochemicals), by competition with pathogens for nutrients or niches and stimulation of induced systemic resistance (ISR) (Compant et al. 2005; Bacon \& Hinton 2006). However, there are few reports of endophytes acting as BCAs in forest trees (Chanway 1998). This delay in their development and application is in part because their performance in the field has not matched their apparent potential when tested in the assay. Thus, a selected endophyte may be replaced by or act differently in the presence of other endophytes already present in the host 
(Newcombe 2011; Hilszczanska 2016).

\section{The efficiency of natural plant products as controlling agents of pest and pathogens}

Synthetic pesticides have been applied during the past few years on a large scale for the management and control of various pest and pathogens of crops and forest trees. Applications of chemical-based pesticides act as helping hand to save the trees of the forest and also of their production (Way and Van Emden, 2000). Due to extensive and continual use of synthetic or chemical pesticides have intruded varied degree of the destructive impact on the biotic and abiotic component of the ecosystem and also create harmful effect to the nontargeting and beneficial organisms (Forage-Elaver, 1989; Rajeskaran and Baker, 1994; Gupta et al., 2015). The excessive use of synthetic pesticides or chemicals act as a toxicant, and these served as poison for the living being. The list of botanicals as controlling agents of against insect pests is provided in Table 1 .

Table 1. Utilization of botanicals as controlling agents of insect pests.

\begin{tabular}{|l|l|l|l|l|}
\hline Name of Plant & Plant products & Biocontrol & Targeted organisms & References \\
\hline Acorus calamus & Acorus & Larvicidal & Aphids and & Bhardwaj et \\
Andica & Azadirachta & & caterpillar & al., 2010 \\
\hline
\end{tabular}




\begin{tabular}{|c|c|c|c|c|}
\hline Allium sativum & Allicin & Insecticidal & $\begin{array}{l}\text { Termites and } \\
\text { Insects }\end{array}$ & $\begin{array}{l}\text { Yang et al., } \\
2009\end{array}$ \\
\hline Cappris decidua & Capparin & Insecticidal & $\begin{array}{l}\text { Termites and } \\
\text { insects }\end{array}$ & $\begin{array}{l}\text { Upadhyay et } \\
\text { al., 2007, 2011, } \\
2012\end{array}$ \\
\hline Cacaliatanguitica & Rotenone & Insecticidal & Complex I inhibitor & $\begin{array}{ll}\text { Lu mmen, } \\
1998\end{array}$ \\
\hline $\begin{array}{l}\text { Chrysanthemum } \\
\text { cineriaefolium }\end{array}$ & Pyrethrum & Insecticidal & Aphids & $\begin{array}{l}\text { Bhardwaj et } \\
\text { al., } 2010\end{array}$ \\
\hline $\begin{array}{l}\text { Croton } \\
\text { urucurana }\end{array}$ & Resin & Larvicidal & Dysderdercusmaurus & $\begin{array}{lll}\text { Silva et al., } & \\
2012 & \end{array}$ \\
\hline $\begin{array}{l}\text { Copaifera } \\
\text { reticulata }\end{array}$ & Oil resin & Larvicidal & Aedes aegypti & $\begin{array}{l}\text { Silva et al., } \\
2007\end{array}$ \\
\hline $\begin{array}{l}\text { Copaifera } \\
\text { multijuga }\end{array}$ & Oil resin & Insecticidal & Anopheles darling & $\begin{array}{l}\text { Trindade et al., } \\
2013\end{array}$ \\
\hline Hot pepper & Capasciacin & Insecticidal & Trichoplusiani & $\begin{array}{l}\text { Annontois et } \\
\text { al., } 2007\end{array}$ \\
\hline Hot pepper & Capasciacin & Insecticidal & Tetranychusurticae & $\begin{array}{l}\text { Edelson et al., } \\
2002\end{array}$ \\
\hline $\begin{array}{l}\text { Diaprepes } \\
\text { abbreviatus }\end{array}$ & Sabadilla & Antifeedant & $\begin{array}{l}\text { Schistocerca } \\
\text { Americana }\end{array}$ & $\begin{array}{l}\text { Sandoval- } \\
\text { Capinara, } \\
2011\end{array}$ \\
\hline
\end{tabular}




\begin{tabular}{|l|l|l|l|l|}
\hline Nicotiana & Nicotine & Toxic and & Sucking insects & Dederer et al., \\
tobacum & Antifeedant & & 2011 \\
\hline
\end{tabular}

Because of their persistent nature for a long duration, these pesticides tend to accumulate in the environment, and hence these are not safe ecologically. Due to their biomagnifications, these chemicals enter into the food chain and thus causes a detrimental effect for the environmental components (Beyer and Biziuk, 2009). Therefore, the large scale use of chemicals or pesticide adversely disturb the food chains and act as a toxicant for the functioning of the beneficial and non-targeted pests. These toxic chemical pesticides function as the damaging and threatening factor for every component of the environment and so on the biodiversity. Different types of insects or pests have gained the resistance or become resistant against the synthetic chemicals or insecticides because the long term exposure of these toxic chemical induces the changes in their genetic makeup, as a consequence of which various types of strains of insects or pests developed, however, most of the insecticides or pesticides are banned (Brattsten et al., 1986; Zettler and Cuperus, 1990). List of essential oil of different plant species used as an insecticidal agent is provided in Table 2 .

Table 2. The essential oil of different plant species as an insecticidal agent.

\begin{tabular}{|l|l|l|l|}
\hline Essential oil & Targeted insect & Biological activity & References \\
\hline Allium sativum & $\begin{array}{l}\text { Lycoriella ingénua } \\
\text { (Dufour) }\end{array}$ & Insecticidal & Park et al., 2006 \\
\hline oil & Rugimanus & Repellent, & Liu et al., 2006 \\
\hline Cedrusdeodara & Phthorimea & Oviposition & Chaudhary et al., \\
\hline
\end{tabular}




\begin{tabular}{|c|c|c|c|}
\hline & operculella & Inhibitor & 2011 \\
\hline Capparis deciduas & Bruchus chinensis & Insecticidal & $\begin{array}{l}\text { Upadhyay et al., } \\
2006\end{array}$ \\
\hline Curcuma longa & $\begin{array}{l}\text { Callosobruchus } \\
\text { maculates }\end{array}$ & Insecticidal & $\begin{array}{l}\text { Tripathi et al, } \\
2002\end{array}$ \\
\hline Cumin & Bruchus chinensis & Insecticidal & $\begin{array}{l}\text { Upadhyay et al., } \\
2007\end{array}$ \\
\hline Eucalyptus oil & Ades albopictus & Repellent, toxic & Yang and Ma, 2005 \\
\hline LanatanaCamara oil & Musca domestica & $\begin{array}{l}\text { Insecticidal \& } \\
\text { Repellent }\end{array}$ & $\begin{array}{l}\text { Abdel Hady et al., } \\
2005\end{array}$ \\
\hline Mentha piperataoil & Ades albopictus & Repellent, toxic & Yang and Ma 2005 \\
\hline Neem seed oil & Tribolium castaneum & $\begin{array}{l}\text { Insecticidal \& } \\
\text { Repellent }\end{array}$ & Koul 2004 \\
\hline Piper nigrum & Tribolium castaneum & Insecticidal & $\begin{array}{l}\text { Upadhyay and } \\
\text { Jaiswal } 2007\end{array}$ \\
\hline Pelargonium sp. & Aeded aegypti & Insecticidal & Ali et al., 2013 \\
\hline
\end{tabular}

Due to the higher level of toxicity, environmental persistency and detrimental effects for the biotic and abiotic components, hence the demand and use of natural plant product as eco-friendly and effective insecticides or pesticides are continuously increased in controlling the disease of crops/forest trees (Ismam, 1955; Alkofahi, 1987). Various plant-based natural products or botanicals (Koshiya and Ghelani, 1993) like Acorus, azadirachtin, nicotine, pyrethroids, and rotenone (Barnby and Klocke, 1987; Ayyangar and Rao, 1989; Deota and Upadhyay, 1993). 
Currently, plant products or extracts are widely utilized as an effectual remedy against the pest and pathogens because of their strong growth and disease inhibitory potential (Koshiya and Ghelani, 1993; Ballesta 2008). Therefore, these natural plant products or biopesticides served as a potent and adequately advantageous substitute for the synthetic chemical for the management of the pest. Nowadays, the application of these environmental friendly biopesticides becoming a prime focus in the field of managed forestry or agroforestry.

\section{Future of biological control}

About $98 \%$ population of pest is controlled or regulated by the natural organisms in any environment. Currently, the use of chemical pesticides or insecticides significantly reduced because of their persistent nature and continuous accumulation in the environment they act as a toxicant for the biotic component of life and causes an environmental health hazard. Therefore, the biocontrol agents becoming an essential tool for controlling the disease incidence of pest and pathogens. In any environment, the emergence and introduction of new predators and parasitoids also act as a good source for the biological control mechanisms. The biocontrol agents are proved as advantageous that the conventional pesticides, but it is highly essential to reshape the other measures of control (like the use of pesticides). These biocontrol agents maintain the ecological balance as these are eco-friendly and does not create any harmful effect for the biotic and abiotic component of the ecosystem and hence much used as a useful measure for the management of the agricultural pest. Currently, biopesticides becoming the centre of attraction of the entire world because of their nonpercistancy and environmentally friendly nature and, hence gaining the momentum. Therefore, the collaboration between the governmental and private sector is essential 
to support the growth, manufacturing, and sale of these eco-friendly biopesticides.

\section{References}

- Abdel-Hady NM, Abdei HAS and Al-Ghabdam AM. (2005) Chemical composition and insecticidal activity of the volatile oils of leaves and flowers of Lantana camara L. cultivated in Egypt. J Soc Parasitol 35: 687-698. https://europepmc.org/article/med/16083076

- Ali A, Tabanca N, Demirci B, Baser KH, Ellis J, Gray S, Lackey BR, Murphy C, Khan IA,Wedge DE. (2013) Composition, mosquito larvicidal, biting deterrent and antifungal activity of essential oils of different plant parts of Cupressus arizonica var. glabra ('Carolina Sapphire'). Nat. Prod. Commun. 8: 257-60.

https://www.ncbi.nlm.nih.gov/pubmed/23513743

- Alkofahi A, Rupprecht JK, Anderson, J E McLaughlin J L and Mikolajczak KL. (1987) A Search for new pesticides from higher plants. Insecticides of plant origin, ACS symposium series 387, Washington, D.C, pp. 24-25.

https://pubs.acs.org/isbn/9780841215696

- Ayyangar GSG and Rao PJ (1989) Neem (Azadirachta indica A. Juss) extracts as larval repellents and ovipositional deterrents to Spodoptera litura (Fab.) Ind J Ent. 51: 121-124.

- Bacon CW, Hinton DM. 2006. Bacterial endophytes: the endophytic niche, its occupants, and its utility. In: Gnanamanickam SS, editor. Plant-associated bacteria. Dordrecht: Springer Publishing; p. 155-194.

- Ballesta AMC, Jascual VM, Rodríguez B. (2008) The antifeedant activity of natural plant products towards the larvae of Spodoptera littoralis, Span J Agr Res 1: 85-91. 
- Barnby MA, Klocke JA. (1987) Effects of azadirachtin on the nutrition and development of the tobacco budworm, Heliothis virescens, J Insect Physiol. 33: 69-75.

- Beyer A, Biziuk M. (2009) Environmental fate and global distribution of polychlorinated biphenyls, in: Reviews of Environmental Contamination and Toxicology Vol 201. Springer, pp. 137-158.

- Bhardwaj A, Tewary DK, Kumar R, Kumar V, Sinha AK and Shanker A. (2010) Larvicidal and structure- activity studies of natural phenylpropanoids and their semisynthetic derivatives.

- Brattsten LB, Holyoke CW, Leeper JR Affa KF. (1986) Insecticide resistance: Challenge to pest management and basic research. Science (Washington). 231: 1125-1128.

- Brawner J, Japarudin Y, Lapammu M, Rauf R, Boden D, Wingfield MJ. 2015. Evaluating the inheritance of Ceratocystis acaciivora symptom expression in a diverse Acacia mangium breeding population. Southern Forests. 77:83-90.

- Chanway C. 1998. Bacterial endophytes: ecological and practical implications. SydowiaHorn. 50:149-170.

- Chaudhary A, Sharma P, Nadda G, Tewary DK, Singh B. (2011) Chemical composition and larvicidal activities of the Himalayan cedar, Cedrus deodara essential oil and its fractions against the diamondback moth, Plutella xylostella. J Insect Sci. 11: 157.

- Compant S, Duffy B, Nowak J, Clément C, Barka EA. 2005. Use of plant growthpromoting bacteria for biocontrol of plant diseases: principles, mechanisms of action, and future prospects. Applied and Environmental Microbiology. 71:4951-4959

- Da HH, Silva, R Geris, Rodrigues Filho, Rocha C. Da and Silva IG. (2007) Larvicidal activity of oilresin fractions from the Brazilian medicinal plant Copaifera reticulate Ducke 
(Legumoinosae-caesalpinoideae) against Aedes aegypti (Diptera: Culicidae). Rev. Soc. Bars Me Trop. 40: 264-267.

- Dederer H and Werr IIg MT. (2011) Differential sensitivity of Ctenophalides felis and Drosophila melanogaster nicotinic acetylcholine receptor $\alpha 1$ and $\alpha 2$ subunits in recombinant hybrid receptors to nicotnoids and neonicotenoid insecticides. Insect Biochem. Mol. Biol.41:51-61.

- Dudley TL, Bean DW (2012) Tamarisk biocontrol, endangered species risk and resolution of conflict through riparian restoration. Biocontrol 57:331-347

- Dyer LA, Carson WP, Leigh EG Jr. 2012. Insect outbreaks in tropical forests: patterns, mechanisms, and consequences. In: Barbosa P, Letourneau DK, Agrawal AA, editors. Insect outbreaks revisited. Hoboken (NJ): Wiley-Blackwell; p. 219-245.

- Edelson JV, Duthie J, Roberts W (2002) Toxicity of biorational insecticides: activity against the green peach aphid, Myzus persicae (Sulzer) Pest Manag Sci. Mar; vol. 58 no. (3),255-60.

- Ferreira MA, Harrington TC, Piveta G, Alfenas AC. (2017). Genetic variability suggests that three populations of Ceratocystis fimbriata are responsible for the Ceratocystis wilt epidemic on kiwifruit in Brazil. Tropical Plant Pathology. 42:86-95

- Forage-Elawer M. (1989) Enzyme and behavioral changes in young chicks as a result carbaryl treatment. J. Toxicol. Environ. Hlth. 26: 119-132.

- Garnas JR, Auger-Rozenberg MA, Roques A, Bertelsmeier C, Wingfield MJ, Saccaggi DL, Roy HE, Slippers B (2016) Complex patterns of global spread in invasive insects: ecoevolutionary and management consequences. Biol Invasions 18:935-952. 
- Goodland T, Healey JR (1996) The invasion of Jamaican montane rainforests by the Australian tree Pittosporum undulatum. School of Agricultural and Forest Sciences, University of Wales Bangor.

- Gupta K, Hardy G, Huang Y, Kenis M, Kimani E (2015) International variation in phytosanitary legislation and regulations governing importation of plants for planting. Environ Sci Policy 51:228-237.

- Hardoim PR, van Overbeek LS, van Elsas JD. 2008. Properties of bacterial endophytes and their proposed role in plant growth. Trends in Microbiology. 16:463-471.

- Harrington TC, Fraedrich SW, Aghayeva DN (2008) Raffaelea lauricola, a new ambrosia beetle symbiont and pathogen on the Lauraceae. Mycotaxon 104:399-404.

- Hayslett M, Juzwik J, Moltzan B, Appel D, Camilli K. (2008). Insect vectors of the oak wilt fungus in Missouri and Texas. In: Proceedings of the 2nd National Oak Wilt Symposium; Austin (Texas). p. 109-120.

- Hilszczańska D. (2016). Endophytes - characteristics and possibilities of application in forest management. Forest Research Papers. 77:276-282.

- Saini I; Aggarwal A, Kaushik P. (2019a). Inoculation with Mycorrhizal Fungi and Other Microbes to Improve the Morpho-Physiological and Floral Traits of Gazania rigens (L.) Gaertn. Agriculture. 9: 51.

- Saini I, Aggarwal A, Kaushik P. (2019b). Influence of Biostimulants on Important Traits of Zinnia elegans Jacq. under Open Field Conditions. International Journal of Agronomy. 3082967: 1-8.

- Ismam MB. (1955) Leads and prospects for the development of new botanical insecticides, in: Roe, R.M. Khur, R.J. (Eds). Rev. Pest. Toxicol. 3: 1-20. 
- Izumi H. 2011. Diversity of endophytic bacteria in forest trees. In: Pirttilä AM, Frank C, editors. Endophytes of forest trees. Dordrecht: Springer; p. 95-105.

- Chauhan J; Saini I; Singh T; Kaushik P. (2020). A Brief Perspective on Acacia a Member of Family Leguminosae. Preprints, 2020060133 (doi:

10.20944/preprints202006.0133.v1).

- Kim DH and Ahn YJ. (2001) Contact and fumigation activities of Foeniculum vulagre fruit against three coleopteran stored product insects. Pest. Manag. Sci. 57: 301-306

- Kiritani K, Yamamura K (2003) Exotic insects and their pathways for invasion. In: Carlton J (ed) Invasive species: vectors and management strategies. Island Press, Washington, pp 44-6

- Kobayashi D, Palumbo J. (2000). Bacterial endophytes and their effects on plants and uses in agriculture. In: Bacon CW, White J, editors. Microbial endophytes. Boca Raton (FL): CRC Press; p. 199-233.

- Koshiya DJ, Ghelani D (1993) Antifeedant activity of different plant derivatives against Spodoptera litura on groundnut, In: Botanical Pesticides in IPM. Symp. Proc. Rajamundry, pp. 175-182.

- Koshiya DJ, Ghelani D (1993) Antifeedant activity of different plant derivatives against Spodoptera litura on groundnut, In: Botanical Pesticides in IPM. Symp. Proc. Rajamundry, pp. 175-182.

- Koul O (2004) Biological activity of volatile di-npropyl disulfide from seeds of neem, Azadirachta indica (Meliaceae), to two species of stored grain pests, Sitophilus oryzae (L.) and Tribolium castaneum(Herbst). J. Econ. Entomol. 97: 1142-1147. 
- Liu CH, Mishar K, Tan RX, Yang H and Shen Y. (2006) Repellent and insecticidal activities of essential oils from Artemisia princeps and Cinnamomum camphora and their effect on seed germination of wheat and broad bean, Technol. Biores. 97: 1969-1973.

- MacLeod A, Pautasso M, Jeger MJ, Haines-Young R (2010) Evolution of the international regulation of plant pests and challenges for future plant health. Food Secur 2:49-70

- Mattson W, Vanhanen H, Veteli T, Sivonen S, Niemela“ P (2007) Few immigrant phytophagous insects on woody plants in Europe: legacy of the European crucible? Biol Invasions 9:957-974

- Muzika RM (2017) Opportunities for silviculture in management and restoration of forests affected by invasive species. Biol Invasions. doi:10.1007/s10530-017-1549-3

- Newcombe G. 2011. Endophytes in forest management: four challenges. In: Pirttalä AM, Frank C, editors. Endophytes of forest trees. Dordrecht: Springer Publishing; p. 251-262.

- Niu HB, Liu WX, Wan FH, Liu B (2007) An invasive aster (Ageratina adenophora) invades and dominates forest understories in China: altered soil microbial communities facilitate the invader and inhibit natives. Plant Soil 294:73-85

- Paine TD, Steinbauer MJ, Lawson SA (2011) Native and exotic pests of Eucalyptus: a worldwide perspective. Annu Rev Entomol 56:181-201.

- Park K, Choi S, Kim DH, Choi IH, Kim LS, Bak WC, Choi JW and Shin SC. (2006) Fumigant activity of plant essential oils and components from horseradish (Armoracia rusticana), anise (Pimpinella anisum) and garlic (Allium sativum) oils against Lycoriella ingenua (Diptera: Sciaridae). Pest. Manag. Sci. 62: 723-728. 
- Rajeskaran M and Baker PP. (1994) Biochemical changes in the liver of house sparrows (Passer domesticus) treated with combinations of pesticides, Indian J. Environ. Toxicol. 4: $37-40$.

- Sandoval-Mojica AF and Capinera JL. (2011) Antifeedant effect of commercial chemicals and plant extracts against Schistocerca americana (Orthoptera: Acrididae) and Diaprepes abbreviatus (Coleoptera: Curculionidae). Pest. Manag. Sci. 67: 860-868.

- Schulz BK, Gray AN (2013) The new flora of northeastern USA: quantifying introduced plant species occupancy in forest ecosystems. Environ Monit Assess 185:3931-3957

- Tarigan M, Roux J, Van Wyk M, Tjahjono B, Wingfield MJ (2011) A new wilt and dieback disease of Acacia mangium associated with Ceratocystis manginecans and $\mathrm{C}$. acaciivora sp. nov. in Indonesia. S Afr J Bot 77:292-304

- Trang TT, Eyles A, Davies NW, Glen M, Ratkowsky D, Mohammed CL. 2018. Screening for host responses in Acacia to a canker and wilt pathogen, Ceratocystis manginecans. Forest Pathology. 48:e12390

- Tripathi AK, Prajapati V, Agarwal KK, Khanuja SPS and Kumar S. (2002) Bioactivities of the Leaf Essential Oil of Curcuma longa (Var. Ch- 66), OnThree Species of StoredProduct Beetles (Coleoptera). J. Economic Entomology. 98: 1391-1398.

- Tsopelas P, Santini A, Wingfield MJ, de Beer ZW. 2017. Canker stain: a lethal disease destroying iconic plant trees. Plant Disease. 101:645-658.

- Upadhyay HP. 1993. Classification of the ophiostomatoid fungi. In: Wingfield MJ, Seifert KA, Webber JF, editors. Ceratocystis and Ophiostoma: taxonomy, ecology, and pathogenicity. St Paul (MN): APS Press; p. 7-13. 
- Upadhyay RK and Ahmad S. (2011) Management strategies for control of stored grain insect pests in farmer stores and public warehouses, World J. Agri. Sci. 7: 527-549.

- Upadhyay RK and Ahmad S. (2012). Ethno-medicinal plants and their pharmaceutical potential. J. Pharmacy Res. 2: 2162-2173.

- Upadhyay RK, Jaiswal G and Yadav N. (2007) Toxicity, repellency and oviposition inhibitory activity of some essential oils against Callosobruchus chinensis. J. Appl. Biosci. 33: $21-26$.

- Van der Putten WH, Klironomos JN, Wardle DA (2007) Microbial ecology of biological invasions. ISME J 1:28-37 Vavra M, Parks CG, Wisdom MJ (2007) Biodiversity, exotic plant species, and herbivory: the good, the bad.

- Vitousek PM, Walker LR (1989) Biological invasion by Myrica faya in Hawai'i: plant demography, nitrogen fixation and ecosystem effects. Ecol Monogr 59:247-265.

- Wardle DA, Bardgett RD (2004) Human-induced changes in densities of large herbivorous mammals: consequences for the decomposer subsystem. Front Ecol Environ 2:145-153.

- Wardle DA, Peltzer DA (2017) Impacts of invasive biota in forest ecosystems in an aboveground-belowground context. Biol Invasions. doi:10.1007/s10530-017-1372-x

- Way MJ, Van Emden HF. (2000). Integrated pest management in practice-pathways towards successful application. Crop protection. 19: 81-103.

- Wingfield MJ, Hammerbacher A, Ganley RJ, Steenkamp ET, Gordon TR, Wingfield BD, Coutinho TA (2008) Pitch canker caused by Fusarium circinatum - a growing threat to pine plantations and forests worldwide. Australas Plant Pathol 37:319-334.

- Wingfield MJ, Kirisits T, Cech TL (2016) Global geographic distribution and host range of Dothistroma species: a comprehensive review. For Pathol 46:408-442 
- Wingfield MJ, Slippers B, Wingfield BD (2010) Novel associations between pathogens, insects and tree species threaten world forests. N Z J For Sci 40(Suppl):S95-S103

- Wolda H. 1988. Insect seasonality: why? Annual Review of Ecology and Systematics. $19: 1-18$.

- Wylie FR, Speight MR 2012. Insect pests in tropical forestry. CABI.

- Yadeta K, Thomma B. (2013). The xylem as battleground for plant hosts and vascular wilt pathogens. Frontiers in Plant Science. 4:1-12.

- Yang FL, Li XG, Zhu F and Lei CL. (2009) Structural characterization of nanoparticles loaded with garlic essential oil and their insecticidal activity against Tribolium castaneum (Herbst) (Coleoptera: Tenebrionidae). J. Agric. Food Chem. 11: 10156-10162.

- Yang P and Ma Y. (2005) Repellent effect of plant essential oils against Aedes albopictus. J. Vector Ecol. 30: 231-234.

- Zettler JL and Cuperus GW. (1990) Pesticide resistance in Tribolium castaneum (Coleoptera: Tenebrionidae) and Rhyzopertha dominica (Coleoptera: Bostrichidae) in wheat, J. Econ. Entomol. 83: 1677-1679.

- Zettler JL and Cuperus GW. (1990). Pesticide resistance in Tribolium castaneum (Coleoptera: Tenebrionidae) and Rhyzopertha dominica (Coleoptera: Bostrichidae) in wheat, J. Econ. Entomol. 83: 1677-1679. 